تأثير استخدام المهارات الحركية الأساسية على بعض المبادئ الخططية

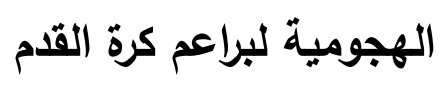

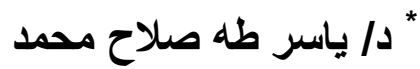

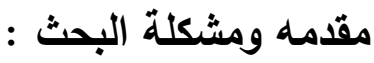

تعد كرة القدم اللعبة الثعبية الأولى في معظم دول العالم وتحظى بالكثير

من الاهتمام والرعاية من رؤساء الدول والحكومات والهيئات ووسائل الإعلام المختلفة ومع انتشار لعبة كرة القدم ازداد عدد الممارسين لها وتسابق الباحثن التهن إلى نشر المؤلفات وإجراء الأبحاث العلمية التي تثتاول اللعبة بالدراسة والتحليل.

كما يعد التدريب الرياضي ميدان خصب لتحقيق ذاتية الطفولة والثباب

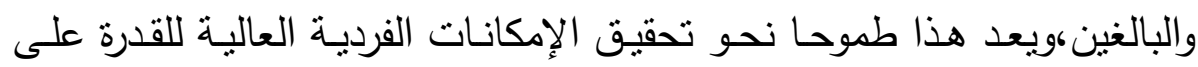

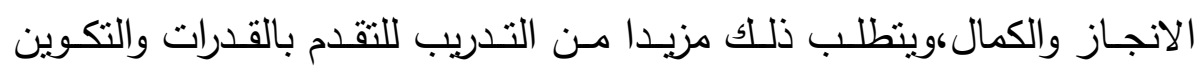
الخاص للشخصية التي يحتاج إليها اللاعب والتي تنعكس على العمل تتظيما

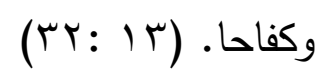

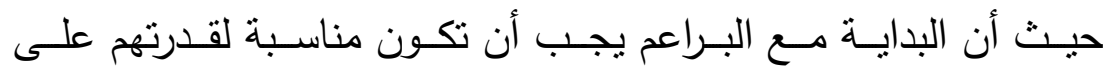

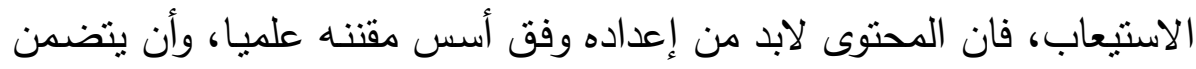

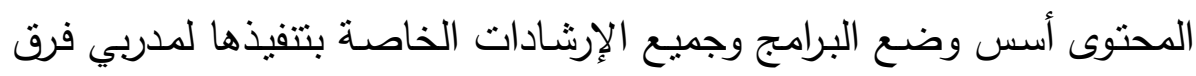

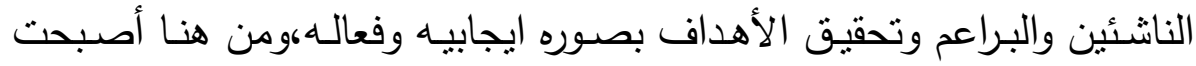

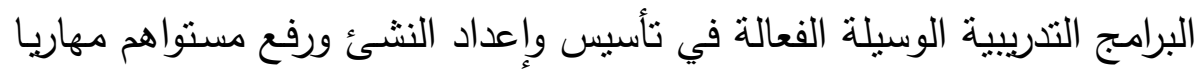

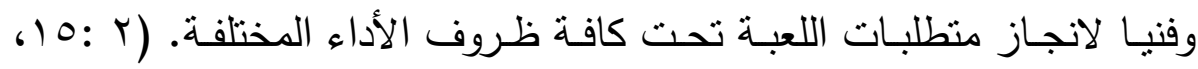

وتعـــــالمهـارات الحركيـة الأساسـية أسـاس جميـع الحركـات المختلفـة

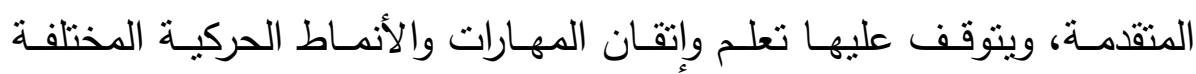

" دكتوراه الفلسفة في التربية الرياضية - كلبية التربية الرياضية ننات- حامعة الإسكندرية مجلة أسيوط للطوم وفنون التربية الرياضية 


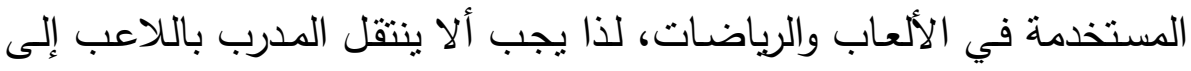
مهارات الألعاب والرياضات إلا بعد أن يتعلم اللاعب ويصل إلى درجه عاليه

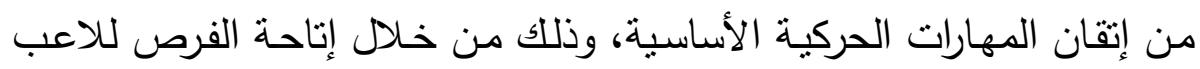

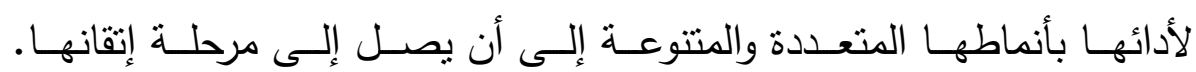

(rTVGrTt: $1 \varepsilon)$

ويعرف "مفتـي (بـراهيم" ( • 99 (م) المبـادئ الخططيـة الهجوميـة بأنها

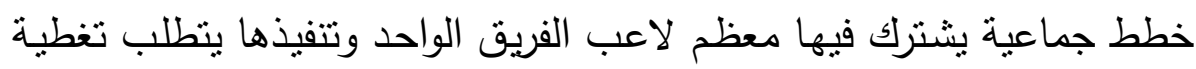

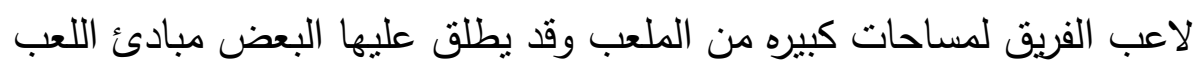

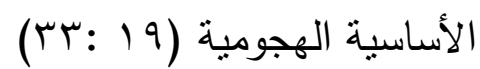

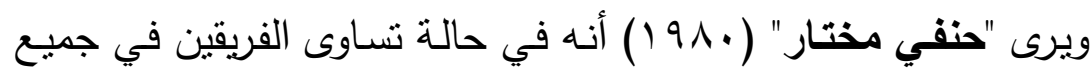

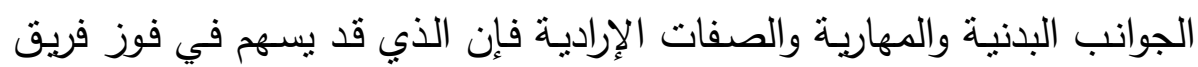
هـ التفوق في الجانب الخططي مـن حيث التصـرف الخططي الهجومي. (7): 1 ) ومن خلال خبرة الباحث كلاعب ومدرب لمرحله با سنة وكذلك من

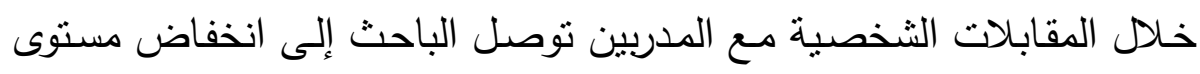

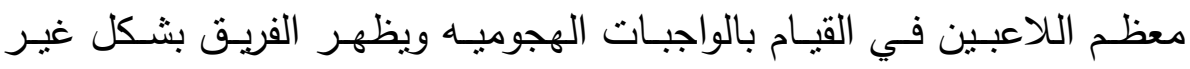
متكامل الأداء، بالرغم من وجود لاعبين على مستوى عالي من الأداء المهاري

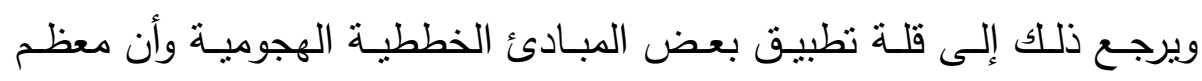

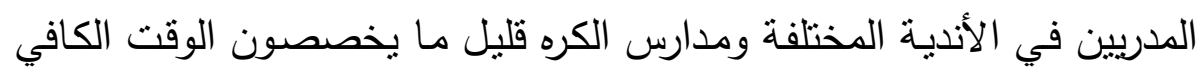
للتنريب على المبادئ الخططية الهجومية.

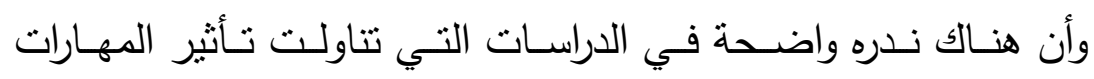

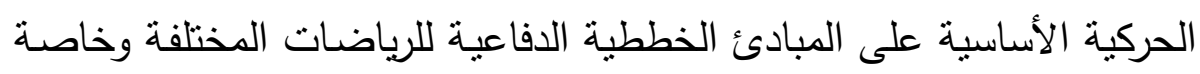
رياضة كرة القدم لهذه المرحلة السنية بالئة السنة. 


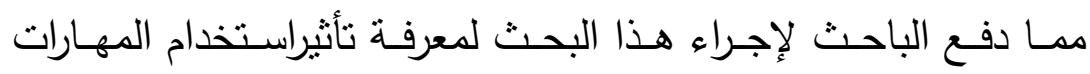

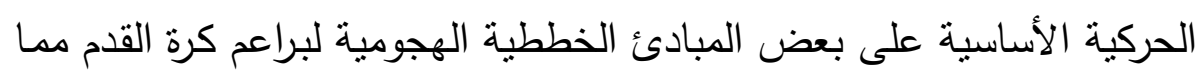

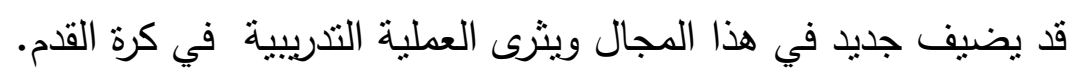
هدف البحث : ملثن

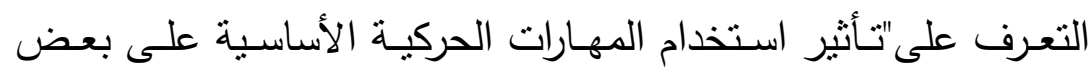
المبادئ الخططية الهجومية لبراعم كرة القدم". فروض البحث : - - توجد فروق دالة إحصائيا بين متوسطات درجات القياس القبلي والقياس

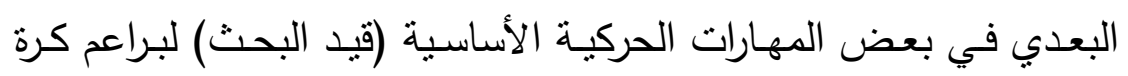
القدم لصالح القياس البعدي.

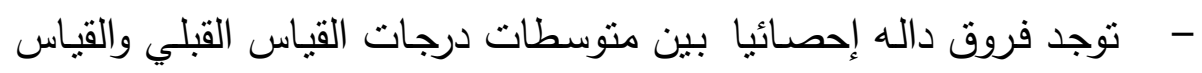

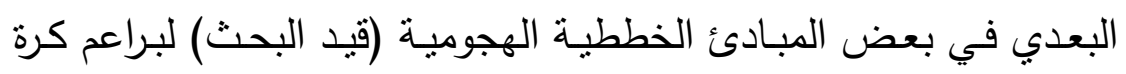
القدم لصالح القياس البعدي.

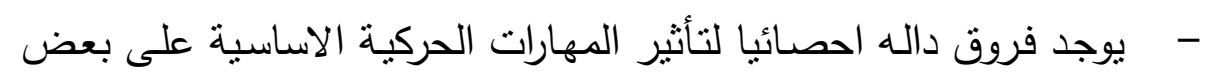
المبادئ الخططية الهجومية.

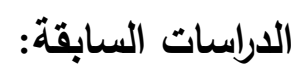

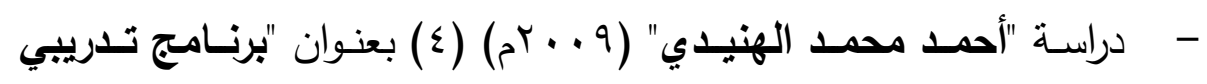

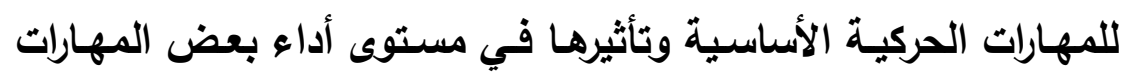

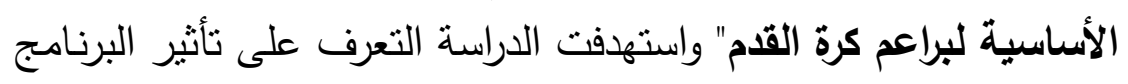

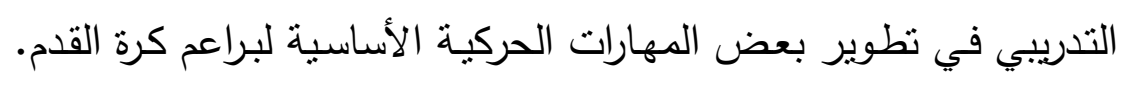

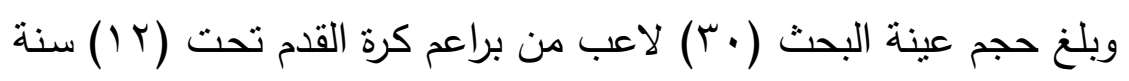

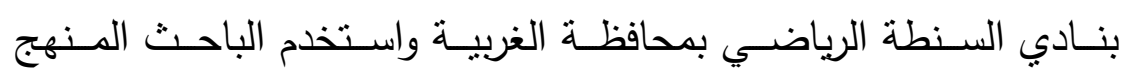

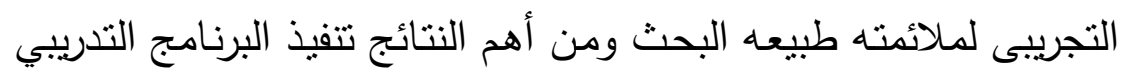

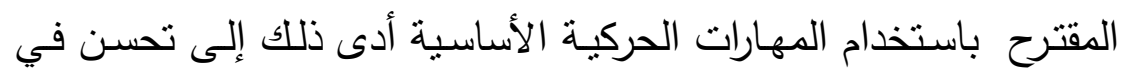
المهارات الأساسية في كرة القدم. مجلة أسيوط لعلوم وفنون التربية الرياضية 


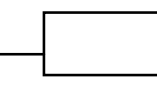

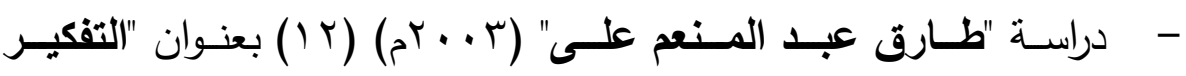

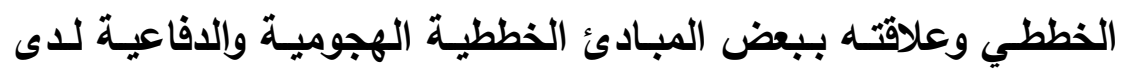

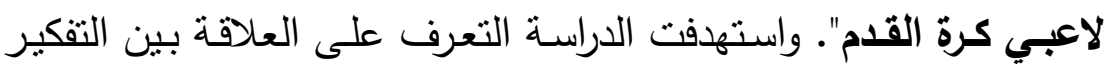

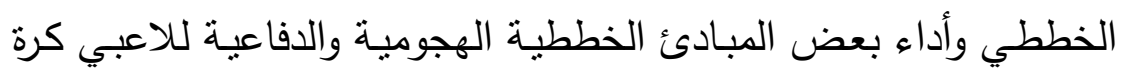

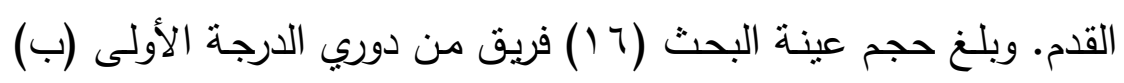

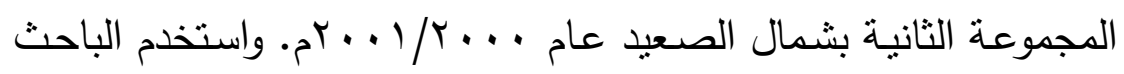

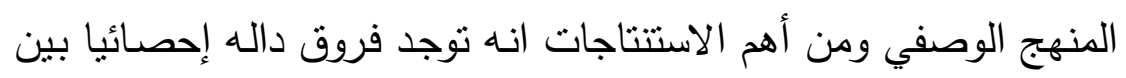

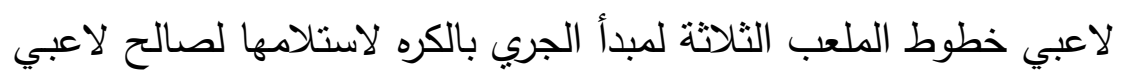

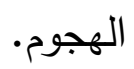

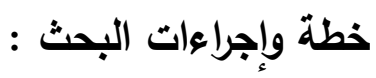
منهج البحث : مطن وإع

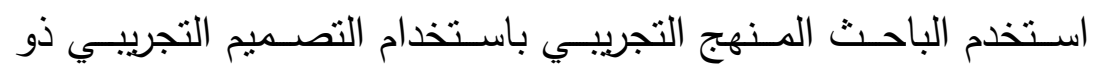

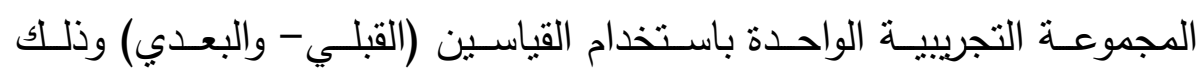
لملائمته لطبيعة البحث.

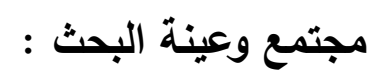
تم اختيـار عينـة البحـث بالطريقـة العمديـة مـن بـراعم نـادي سـوهاج

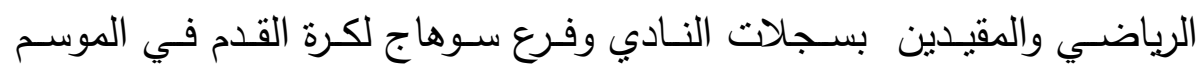

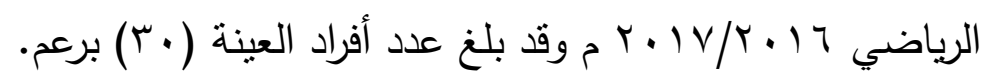

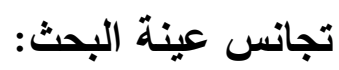
للتأكد من وقوع أفراد عينة البحث تحثت البحت المنحنى الاعتدالى،قام الباحث

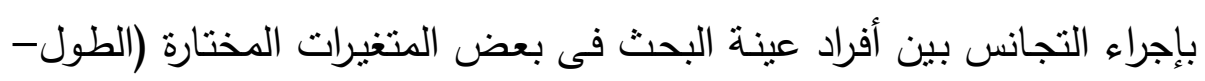

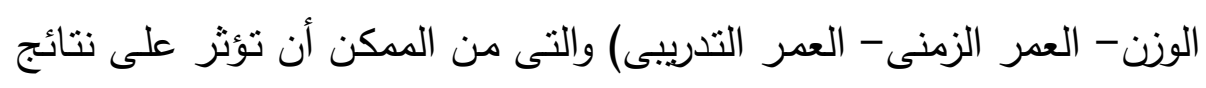
الدراسة كما يتضح من الجداول التالية.

مجلة أسيوط لعلوم وفنون التربية الرياضية 
جدول (1)

تجانس أفراد العينة قيد البحث (ن= • (1)

\begin{tabular}{|c|c|c|c|c|c|c|}
\hline التقلطح & الإلتواء & الإنحرياري & الحستبي & القياس & الاختبارات & م \\
\hline$. .01-$ & $\begin{array}{c}- \\
. . K r\end{array}$ & $0.1 \mathrm{~V}$ & $1 \leqslant V .1 V$ & سم & الطول & 1 \\
\hline$\cdot Y_{I}-$ & $\begin{array}{l}- \\
. .1 \leqslant \\
\end{array}$ & $\vee . V q$ & $\varepsilon r . \mid r$ & كجم & الوزن & r \\
\hline $1.00-$ & $\begin{array}{c}- \\
\therefore .00 \\
\end{array}$ & $\cdot . \leqslant \Lambda$ & $11.7 \mathrm{~V}$ & سنة & العمر الزمنى & r \\
\hline$\cdot . \wedge r-$ & $\begin{array}{l}- \\
\mu \\
\end{array}$ &. Y A & T.VY & سنة & العمر التدريبي & $\varepsilon$ \\
\hline
\end{tabular}

حد الدلالة للتقلطح=0 v . 1.

حد الدلالة للإلتواء=

يتضح من نتائج جدول (r) أن قيم معامل الالنواء تراوحت ما بين

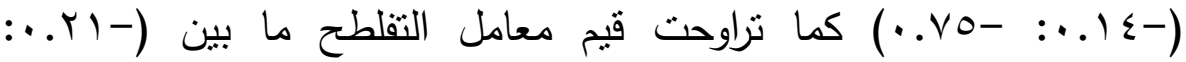

- 1.00)، وهما أقل من حد الدلالة للإلنتواء والتقلطح، مما يشير إلى أن العينة

موزعة توزيعا إعتدالياً في متغيرات (الطول، الوزن، العمر الزمني، العدر التدريبي) قيد البحث.

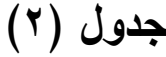

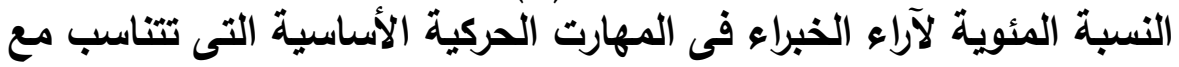

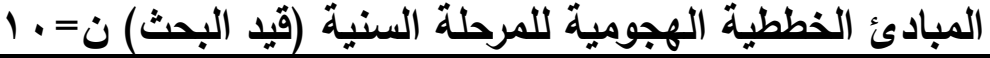

النسبة المئوية

عدد الموافقة

المهارات الحركية الاساسية

r

\begin{tabular}{|c|c|c|c|}
\hline$\% 1 \ldots$ & 1. & المشي & 1 \\
\hline$\% 1 \ldots$ & 1. & الجرى & $r$ \\
\hline$\% 1 \ldots$ & 1. & الوثب & r \\
\hline$\% 1 \ldots$ & 1. & الحجل & $\varepsilon$ \\
\hline$\% 1 \ldots$ & 1. & الضرب & 0 \\
\hline$\% 1 \ldots$ & 1. & الركل & 7 \\
\hline \multicolumn{2}{|c|}{ لة أسيوط لعلوم وفنون التربية الرياضية } & & \\
\hline
\end{tabular}




\begin{tabular}{|c|c|c|c|}
\hline$\% 1 \ldots$ & 1. & التوازن الثابت & $v$ \\
\hline$\%$ r. & $r$ & التوازن المتحرك & $\wedge$ \\
\hline$\% \leqslant$. & $\varepsilon$ & الثنى & 9 \\
\hline
\end{tabular}

يوضح جدول (Y) استخلاص (V) مهارات حركية أساسية نتناسب مع

المبادئ الخططية الهجومية لبراعم كرة القدم مواليد (Y) (انة وهى (المشى، الجري، الوثب، الحجل، الضرب، الركل، التوازن الثابت) وقد استبعد الباحث المهارات الحركية الاساسية التى تقل فيها النسبة المئوية لاراء الخبراء عن

\section{جدول (ب)}

النسبة المئوية وفقا لأراء الخبراء فى المبادئ الخططية الهجومية

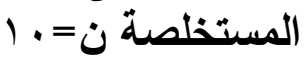

\begin{tabular}{|c|c|c|c|}
\hline النسبة المئوية & عدد الموافقة & المبادئ الخططية الهجومية & b \\
\hline$\% 1 \ldots$ & 1. & العمق في الهجوم & 1 \\
\hline$\% 1 \ldots$ & 1. & الاتساع في الهجوم & r \\
\hline$\% \wedge$ & $\Lambda$ & السند في الهجوم & $r$ \\
\hline$\% \vee$. & $\mathrm{V}$ & الزياده العدديه في منطقة الكره. & $\varepsilon$ \\
\hline$\%$ \%. & $r$ & التغلب على مصبدة التسلل. & 0 \\
\hline$\%$ r. & r & 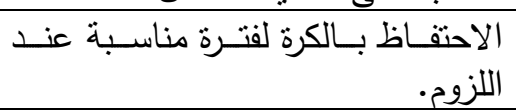 & 7 \\
\hline$\% r$. & r & تبادل المراكز . & $v$ \\
\hline$\% 1$. & 1 & الجري الحر • & $\Lambda$ \\
\hline
\end{tabular}

يوضـح جـدول (ب) اسـتخلاص (ع) مبـادئ خططيـة هجوميـة المناسـبة للمرحلة السنية (قيد البحث) وفقا لآراء الخبراء. يتضـح مـن جدول (r) اسـتخلاص(ع) مبـادئ خططيـة هجوميـة هـى (العمق في الهجوم- الاتسـاع في الهجوم- السند في الهجوم- الزياده العدديـ في منطقة الكره ). 
وقد استبعد الباحث المبادئ الخططية الهجومية التى تقل فيها النسبة

المئوية لآراء الخبراء عن .0\%.

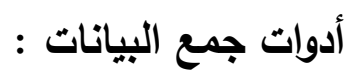

إستعان الباحث في جمع البيانات بالأتي : البانات :

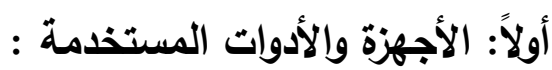

- أقماع بلاستيك - ساعة إيقاف - شريط قياس - ميزان طبي - أعلام صغيرة-

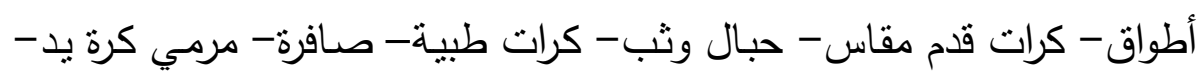

$$
\text { ثقانيا: الإختبارات سويدي- عصى. }
$$

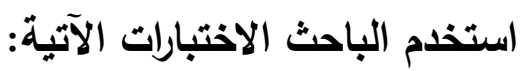

تم إختبـار مجموعـة مـن الاختبـارات لقياس كفـاءة البراعم فى المهارات

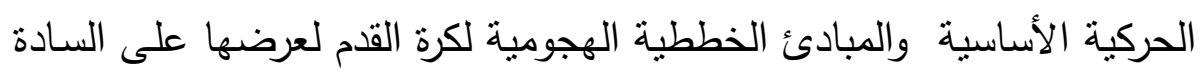

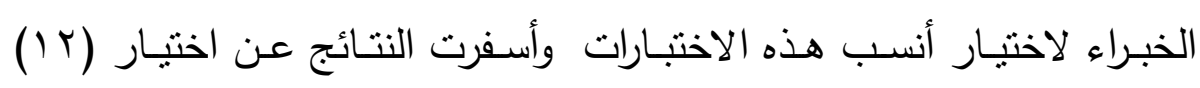

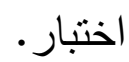

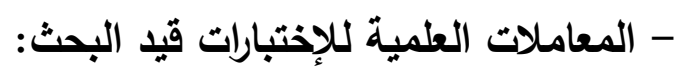
- المعاملات العلمية للاختبارات المهارات الحركية الاساسية.

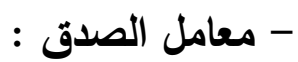

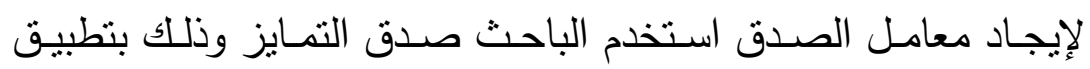

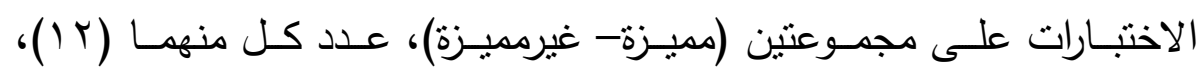

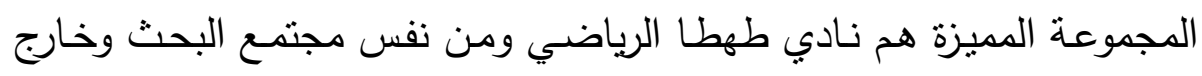

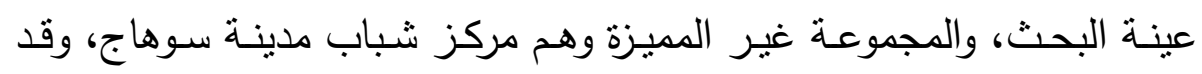

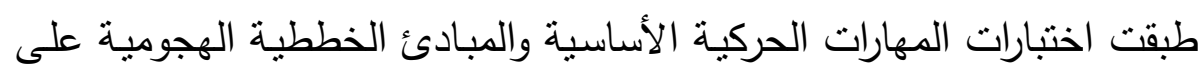

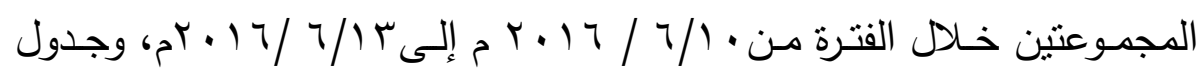
(؟) يوضح دلالة الفروق بين المجموعنين. مجلة أسيوط للعوم وفنون التربية الرياضية 
$\Delta \quad \square$ 


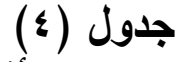

دلالة الفروق بين متوسطات القياسات لأفراد المجموعتين المميزة والغير

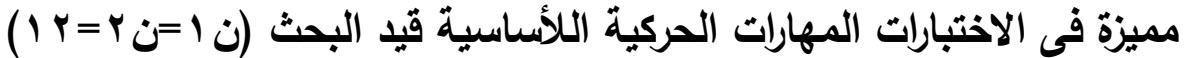
$(r \leq=\dot{0})$

\begin{tabular}{|c|c|c|c|c|c|c|c|}
\hline \multirow[t]{2}{*}{ قيمة ت } & \multicolumn{2}{|c|}{ مجموعةغيز } & \multicolumn{2}{|c|}{ مجموعة مميزة } & \multirow{2}{*}{ والقياس } & \multirow[t]{2}{*}{ الاختبار ات } & \multirow[t]{2}{*}{ م } \\
\hline & $\varepsilon^{+}$ & 5 & $\varepsilon^{+}$ & 5 & & & \\
\hline$* \vee \vee \vee 9-$ &. .97 & $11.1 \leq$ &. .71 & 1. $\leqslant 9$ & ثانية & المشي ه广متز & 1 \\
\hline$* 0.11-$ &..$\varepsilon Y$ & 0.9. & . . & $0 . .1$ & ثانية & عدو .ب مثز & r \\
\hline$* \vee .17$ & r..人 & TY.YO & r.9 & r.OA & سم & الوثب العمودي & r \\
\hline *T.TY- & מצ.. & r.71 & וT & I.Y & ثانية & الحجل · اليمنز بالقدم & $\varepsilon$ \\
\hline$* \varepsilon-$ & דצח. & r.vᄉ &.$r q$ & r. ro & ثانية & الحجل · اليسرى بالقدم & 0 \\
\hline *17. r & $.0 \%$ & r. $\varepsilon \varepsilon$ & $\cdot . \leqslant \wedge$ & 7.10 & متز & ضرب الكرة بالرأس & 7 \\
\hline$* 1 . . \vee 7$ & 1.87 & IT.rq & 1.90 & $r .0 \leqslant$ & متز & ركل الكرة للأمام & 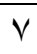 \\
\hline$* 1 \cdot \ldots \leqslant$ & $\varepsilon . \leqslant 7$ & $7.1 \mathrm{~V}$ & $1 \varepsilon .11$ & o..v & ثانية & التوازن التثابت & $\Lambda$ \\
\hline
\end{tabular}

قيمة "ت" الجدولية عند مستوى 0 . . V V . . . . دال عند مستوى (0. . ) يتضـح من جدول (؛ ) وجـود فروق ذات دلالـة إحصـائية عند مسـتوى (0 . . •) بـين المجهـوعتين المميـزة وغيـر المميـزة حيـث تراوحـت قيمـة "ت

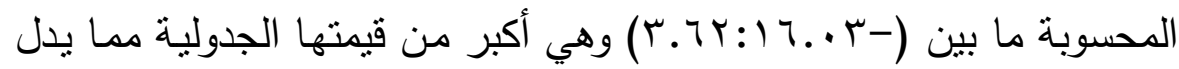
على قدرة الاختبار على التمييز بين المجموعات المختلفة.

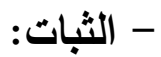
لإيجـاد معامل الثبات استخدم الباحث طريقة تطبيق الإختبار وإعـادة التطبيـق على عينـة قوامها (Y ( ) لاعب مـن نـادي طهطـا الرياضـي مواليد (Y (سنة)، والسابق استخدامها في إيجاد الصدق وبفارق زمني قدره (V) ايام

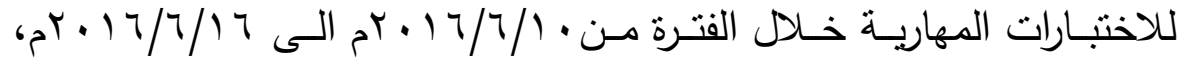
وجدول (0) يوضح ذلك. 
جدول (0)

معامل الارتباط بين التطبيقين الأول والثاني في اختبارات المهارات الحركية

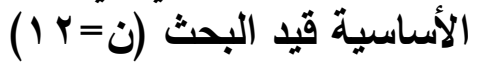

\begin{tabular}{|c|c|c|c|c|c|c|c|c|}
\hline \multirow{2}{*}{ "ر" } & \multirow{2}{*}{ المتوسطات } & \multicolumn{2}{|c|}{ التطبيق الثاني } & \multicolumn{2}{|c|}{ التطبيق الأول } & \multirow{2}{*}{ وحدة القياس } & \multirow{2}{*}{ الاختبارات } & \multirow{2}{*}{ r } \\
\hline & & $\varepsilon^{+}$ & 5 & $\varepsilon^{+}$ & 5 & & & \\
\hline$* . \wedge V$ & .011 &. .79 & ר. 1. &. .71 & 1. $\leqslant 9$ & ثانية & هبمير & 1 \\
\hline *. .94 & מ... & $\cdot . \leqslant 1$ & $\varepsilon .91$ & . . & $0 . .1$ & ثانية & منز & r \\
\hline$* . \wedge r$ & $1 \ldots$ & r.Ar & ג.01" & r.9 & Tr.o1 & سم & الوثبودي & r \\
\hline$* .94$ & $\cdots v$ &.$r q$ & r.r人 & . I I & r.Y & ثانية & الحجل اليمنى بالقدم & $\varepsilon$ \\
\hline$* .99$ &..$r$ &.$r \Lambda$ & r.tV &.$r q$ & r.ro & ثانية & الـاليسرى المتر بالقدم & 0 \\
\hline$* . .94$ & $\ldots r$ &..$\leqslant 7$ & $7 . V T$ & $\cdot . \leqslant \Lambda$ & 7.10 & متز & ضرب الكرة بالرأس & 7 \\
\hline$* .9 V$ & 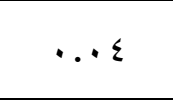 & 1.94 & $r . .0$. & 1.90 & $r . .0 \leqslant$ & منز & رلأمام $\quad \quad \quad \quad$ الكرة & V \\
\hline$* .99$ & $1 . .9$ & 11.17 & $01.1 Y$ & $1 \leq .1 T$ & r . . & ثانية & التوازن الثابت & $\wedge$ \\
\hline
\end{tabular}

يتضح من جدول (0) أن هناك معامل ارتباط دال إحصائيا بين

القياسين الأول والثاني في الاختبارات المهارية مما بدل على ثبات تثلك

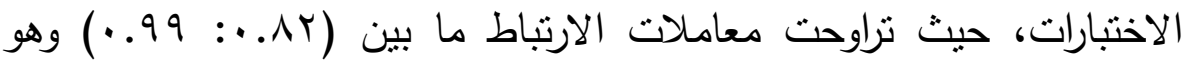

$$
\text { أكبر من قيمة " ر " الجدولية عند مستوى (0 ( . . ). }
$$

دلالة الفروق بين متوسطات القياسات لأفراد المجموعتين المميزة والغير

\begin{tabular}{|c|c|c|c|c|c|c|c|c|}
\hline \multirow[t]{2}{*}{ قيمة"ت" } & \multirow{2}{*}{ فروق المتوسطات } & \multicolumn{2}{|c|}{ غير المميزة } & \multicolumn{2}{|c|}{ المميزة } & \multirow{2}{*}{ القياس } & \multirow{2}{*}{ المتغير } & \multirow[b]{2}{*}{ م } \\
\hline & & $\varepsilon_{-}^{+}$ & r & $\varepsilon_{-}^{+}$ & 5 & & & \\
\hline * " & $\quad . r V$ & $\therefore \leqslant V$ &.$\mu^{\mu}$ & .0. &. $.0 \mathrm{~V}$ & عدد & العقق في الهجوم & 1 \\
\hline
\end{tabular}

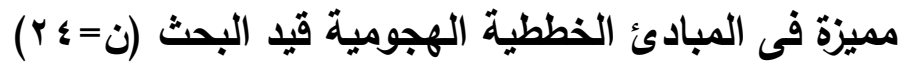




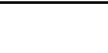

\begin{tabular}{|c|c|c|c|c|c|c|c|c|}
\hline$* Y .10$ & .07 &.$\leqslant 0$ &.$r V$ & .01 & .01 & عدد & الاتساع في الهجوم & $r$ \\
\hline *Y.11 &. .57 &..$\leqslant 9$ & ע & $\cdot . \leqslant 9$ & r & عدد & السند في الهجوح & $r$ \\
\hline *Y.11 &.$T V$ &..$\leqslant \wedge$ & אז.. & .0. & .7. & عدد & الزياده العدديه في & $\varepsilon$ \\
\hline
\end{tabular}

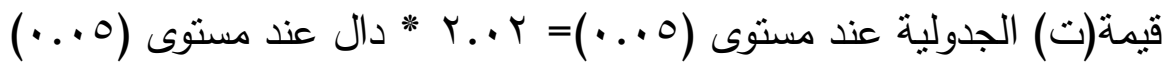

يتضح من جدول (†) وجود فروق دالة إحصائيا بين المجموعتين غير

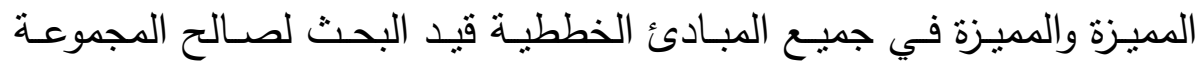

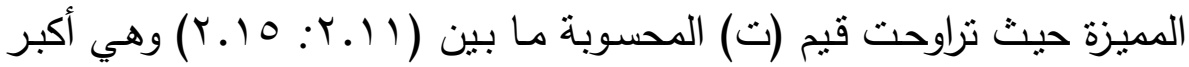
من قيمتها الجدولية عند مستوى (0 . . ) مما يدل على صدق استمارة تحليل المبادئ الخططية قيد البحث. مئ.

\section{الموضوعية :}

موضوعية استمارة تحليل المبادئ الخططية الهجومية المرتبطة قيد البحث: قام الباحث بتصوير مباراة من خارج عينة البحث ومن مجتمع البحث لفريقين من نادي طهطا الرياضي بسوهاج عدد كل فريق ^ براعم وقام بتحليل المباراة ثم عرضها على أحد الزملاء المساعدين حيث قام بتحليل نفس المباراة لنفس اللاعبين ثم قام بتجميع البيانـات للمرة الأولى والثانيـة وكانت والنتائج واحدة تقربيا.

- إعتدالية العينة في اختبارات المهارات الحركية الأساسية : جدول (v)

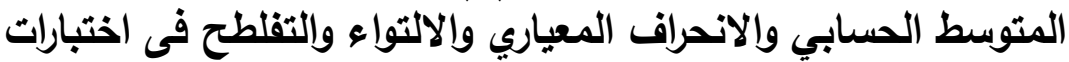

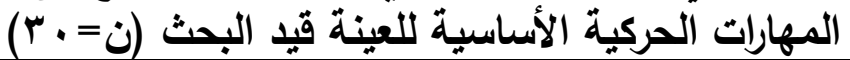

\begin{tabular}{|c|c|c|c|c|c|c|}
\hline التقلطح & الالتواء & $\varepsilon \pm$ & b & وحدة القياس & الاختبارات & r \\
\hline .10 &. $.7 \mathrm{~V}$ & $1 . Y \varepsilon$ & q. $\Sigma V$ & ثانية & المشي هץمتر & 1 \\
\hline. .91 & $\cdot . \wedge \varepsilon$ &.$M V$ & 0.19 & ثانية & عدو • ب مثز & r \\
\hline $.19-$ &.$Y_{T}$ & 0.11 & r. $1.7 \mathrm{~V}$ & سم & الوثب العمودي & r \\
\hline$. .19-$ & $\cdot . \wedge$ &..$\leqslant Y$ & r.lv & ثانية & الحجل · امتر بالقدم اليمنى & $\varepsilon$ \\
\hline
\end{tabular}




\begin{tabular}{|c|c|c|c|c|c|c|}
\hline$\cdot . \varepsilon \cdot-$ &..$\vee 7$ & 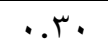 & r..o & ثانية & الحجل · (متر بالقدم اليسرى & 0 \\
\hline$. .01-$ & $.10-$ & $1 . \varepsilon r$ & $0 . \varepsilon$. & منز & ضرب الكرة بالرأس & 7 \\
\hline$\cdots 9-$ & . TO & r.tr & $1 \vee .1 \cdot$ & 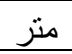 & ركل الكرة للأكام & V \\
\hline$. .77-$ & $\cdot . \wedge \varepsilon$ & $r \varepsilon \ldots+1$ & $r \leq .9$. & ثانية & التوازن الثابت & $\wedge$ \\
\hline
\end{tabular}

حد الدلالة للتقلطح=0 v.

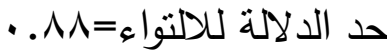

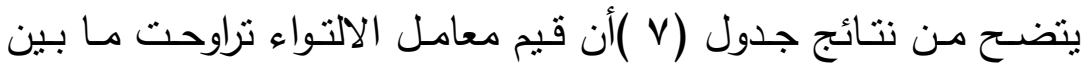

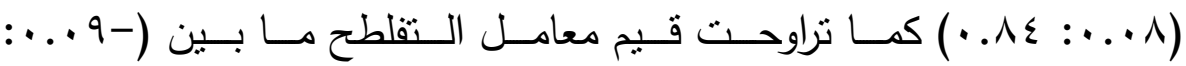
- 9 - . )، وهما أقل من حد الدلالة للإلتواء والتفلطح، مما يشير إلى أن العينة موزعة توزيعا إعتدالياً في المهارات الحركية الأساسية قيد البحث. هن ثالثاً: التخطيط الزمني لتنفيذ التدريبات للبرنامج التدريبي.

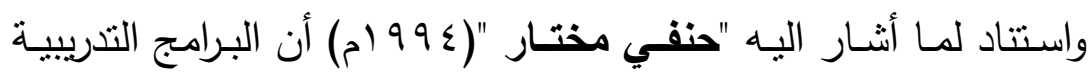

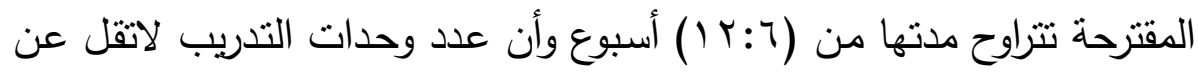
(r) وحـدات أسـبوعية وأن هـذه الفترة تكـون كافيـة لظهـور التـأثثر البـدني. $(\vee Y: q)$ لذلك يـرى الباحث أن مدة (Y I) أسبوع كافيـة لتحقيق أهداف البحث

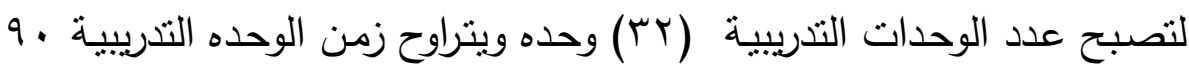
دقيقة تطبق على المجموعة التجريبية. خطوات تثقيذ البحث

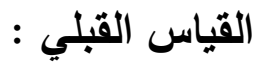

قـام الباحــث بـاجراء القبـاس القبلــي فـى الفتـرة مــن يـوم السـبت

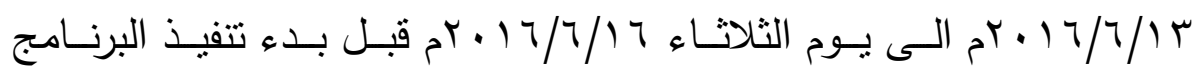
التثربيجي. تطبيق البرنامج التدريبي: تم تطبيق البرنامج التدريبي على اللاعبين (عينة البحث) فى الفترة من

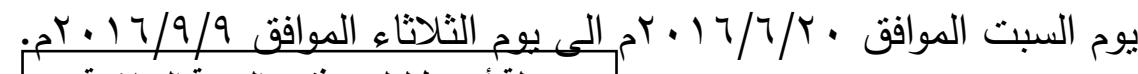
مجلة أسيوط لعلوم وفنون التربية الرياضية 
قام الباحث بـإجراء القياس البعدي يوم السبت الموافق r r/9/9 1 • بام الى يوم الثلاثاء الموافق 0 7/9/1 1 ـ بم بعد الاسبوعين الثاني عثر (انتهاء المعالجات الإحصائية التدريبي)

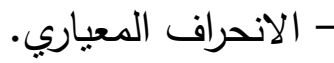

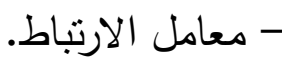
- التقلطح.

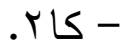

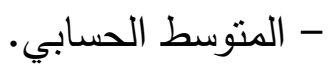

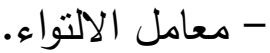

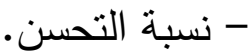
- اختبار (ت) (ت) - (ت) عرض النتائج عرض نتائج الفرض الأول الأي ينص على : - توجد فروق دالة إحصائياً بين منتسطي القياسين القبلي والبعدي لصالح القيـاس البعـدي للمجموعـة التجربييـة فـي المهـارات الحركيـة الأساسـية

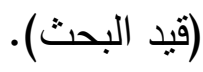

\section{جدول (^)}

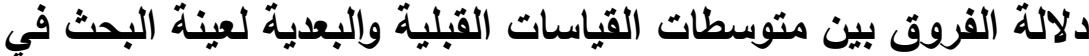

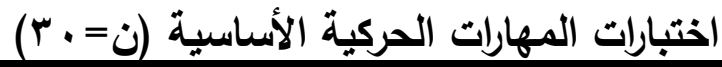

\begin{tabular}{|c|c|c|c|c|c|c|c|c|c|}
\hline \multirow{2}{*}{ قالمحسوبة ت } & \multirow{2}{*}{ فروق المتوسطات } & \multirow{2}{*}{ نسبة } & \multicolumn{2}{|c|}{ القياس البعدي } & \multicolumn{2}{|c|}{ القياس القبلي } & \multirow{2}{*}{ وحدة القياس } & \multirow{2}{*}{ الاختبار ات } & \multirow{2}{*}{ م } \\
\hline & & & $\varepsilon$ & r & $\varepsilon$ & r & & & \\
\hline *ITr.r & r.or & r.. & .01 & $7.9 \leq$ & $1 . Y \varepsilon$ & $q . \leqslant V$ & ثانية & هبمتر & 1 \\
\hline$*|T . Y|$ & 1.11 & rV.97 &. ro & $\varepsilon . Y_{1}$ &.$r V$ & 0.19 & ثانية & عدو • منر & r \\
\hline *) & q.Vr & $r . . v \varepsilon$ & r. $\leqslant 0$ & $\varepsilon 1 . \varepsilon$. & 0.11 & TI. & سم & العمودي & r \\
\hline$* 10.19$ & $\cdot .9$ & $r 9.79$ &.$r$. & T.TV & $\cdot . \leqslant Y$ & r.IV & ثانية & الحجل • المتر & $\varepsilon$ \\
\hline
\end{tabular}

مجلة أسيوط لعلوم وفنون التربية الرياضية 


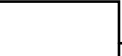

\begin{tabular}{|c|c|c|c|c|c|c|c|c|c|}
\hline *I Y.TV &.$V r$ & $\Gamma \cdot . \wedge \varepsilon$ &. $.1 \mathrm{~V}$ & سז.r &.$r$. & r. o & ثانية & الحجل • المتر & 0 \\
\hline$* V . r Y$ & $r . \Sigma V$ & $\varepsilon 0 . V 7$ & 1.70 & $V . \wedge V$ & $1 . \Sigma Y$ & $0 . \varepsilon$. & متز & ضرب الكرة & 7 \\
\hline$* \backslash \wedge . \wedge \wedge$ & 11.29 & TV.Y. & r.vr & YA. .09 & T.rV & 18.1. & متر & ركل الكرة & V \\
\hline *Y.^r & $1 \pi . . r$ & OY.EY & Yr.Aq & rV.Ao & $r \varepsilon \ldots A$ & $r \varepsilon . \wedge r$ & ثانية & التوازن الثابت & $\Lambda$ \\
\hline
\end{tabular}

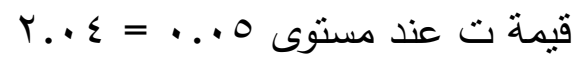

يتضـح من نتائج جدول (^) وجود فروق دالة إحصـائياً بين منوسطي القياسين القبلي والبعدي في اختبارات المهارات الحركية الأساسية قيد البحث

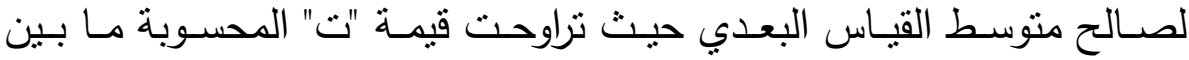

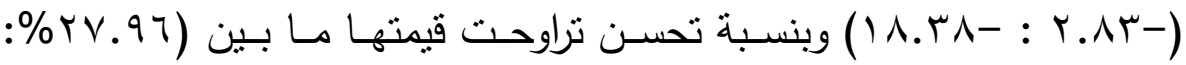

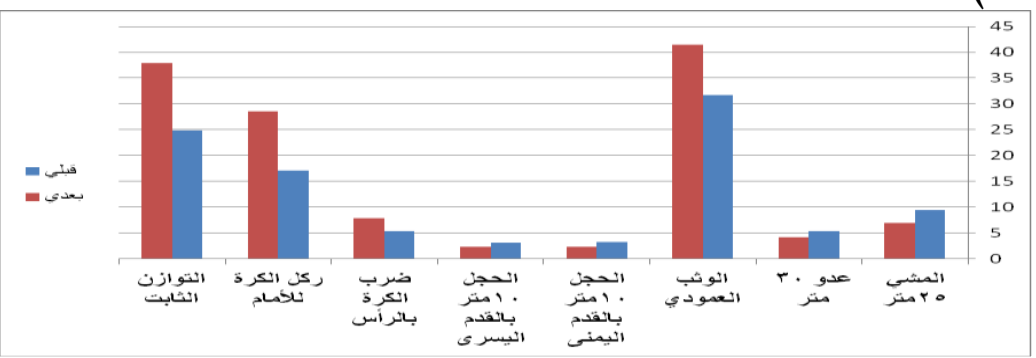

عرض نتائج الفرض الثاني والذى ينص على: - - توجد فروق دالة إحصائياً بين متوسطي القياسين القبلي والبعدي لصالح القياس البعدي للمجموعة التجربيية في بعض المبادئ الخططية الهجومية

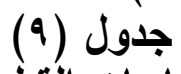

$$
\text { المرتبطة بكرة القدم (قيد البحث). }
$$

دلالة الفروق بين متوسطات القياسات القبلية والبعدية في المبادئ الخططية

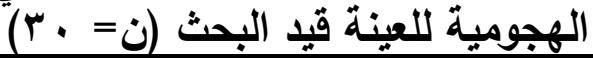

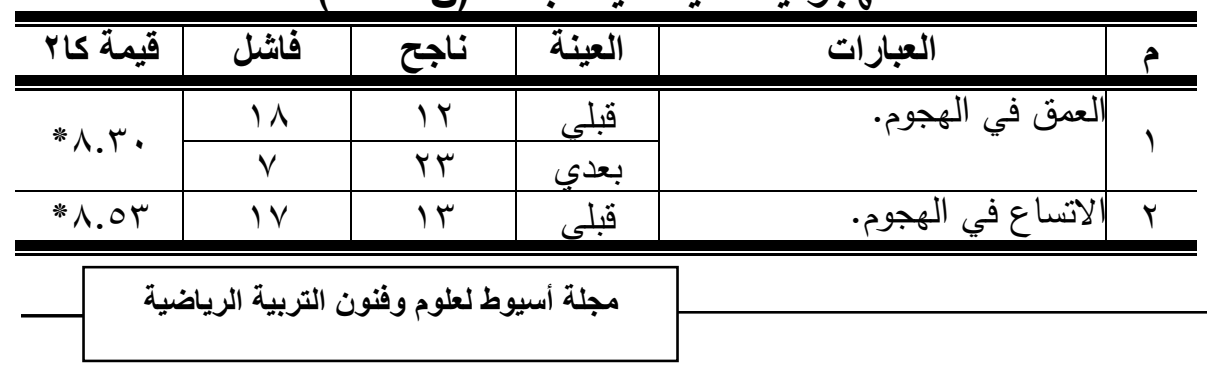




\begin{tabular}{|c|c|c|c|c|c|}
\hline & 7 & $r \varepsilon$ & بعدي & & \\
\hline \multirow{2}{*}{$* \vee .0$. } & 10 & 10 & قبلى & \multirow{2}{*}{ |السند في الهجوم. } & \multirow{2}{*}{ r } \\
\hline & 0 & ro & بعدي & & \\
\hline \multirow{2}{*}{$* 0 . \vee 1$} & 17 & $1 \varepsilon$ & قبلي & \multirow{2}{*}{ الزياده العدديه في منطقة الكره. } & \multirow{2}{*}{$\varepsilon$} \\
\hline & V & rr & بعدي & & \\
\hline
\end{tabular}

قيمة كاب عند مستوى (0. . • = يتضـح من جدول (9) وجود فروق دالة إحصـائيا عند مستوى (0 . • ) بين القياسين القبلي والبعدي في المبادئ الخططية الهجومية حيث تراوحت قيمة

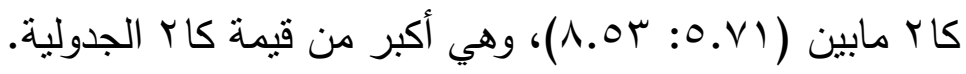
- مناقشة النتائج وتفسيرها: - مناقشة نتائج الفرض الأول الأبي ينص فله على:

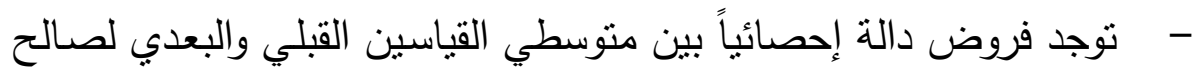

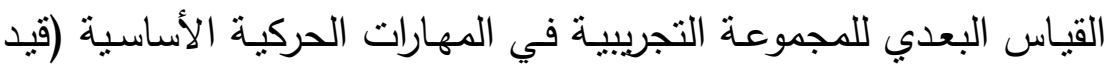

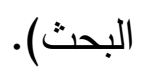

يتضـح لنا من جدول (^) وشكل ( () وجود فروق ذات دلالة إحصـائياً

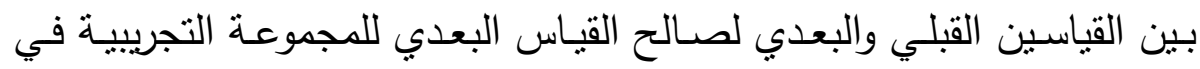

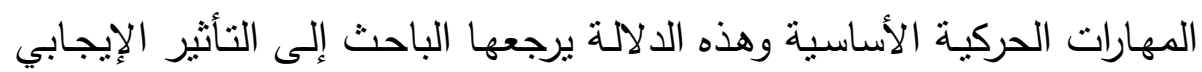

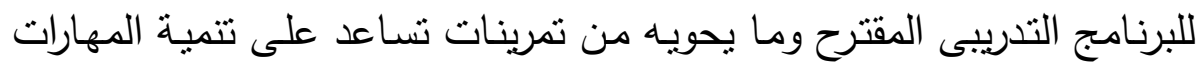
الحركيـة الأساسية للاعبين مـن خـلال أسـاليب تدريبية مشـوقة وممتعسة ومثيرة

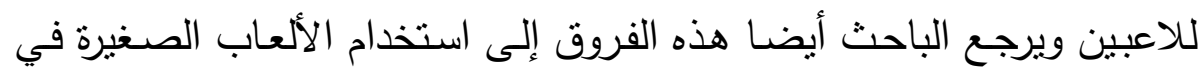

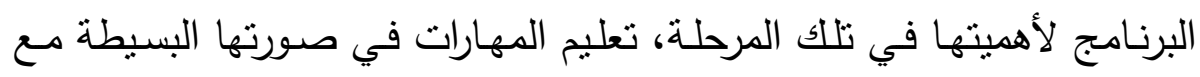
الإكثار من تمرينات الإحساس بالكره، ومراعاة تطبيق المهارات التي تم تعليمها

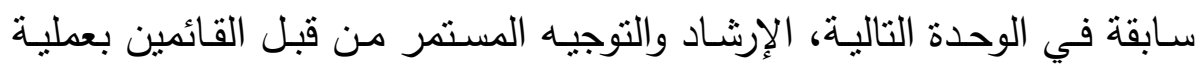
التربب، كذلك استخدام الباحث لإسلوب التربية الحركية الذي يتناسب مع هذه ونه

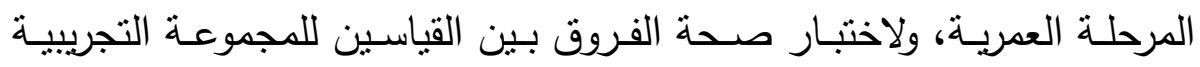

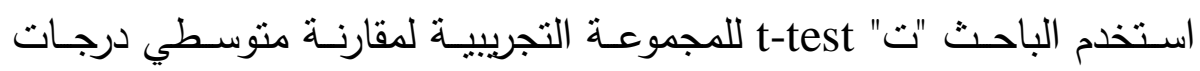

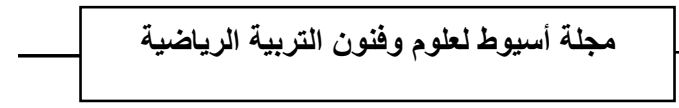


اللاعبين في القياس القبلي والبعدي لاختبارات المهارات الحركية الأساسية، كما

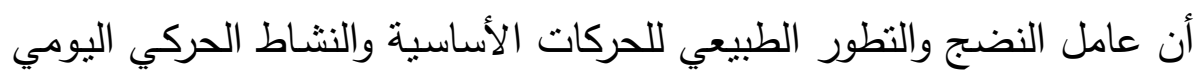

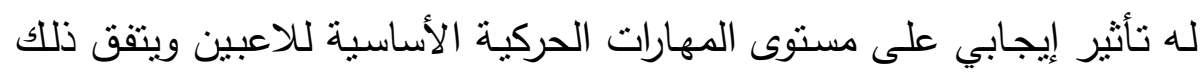

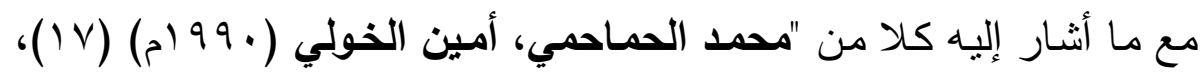

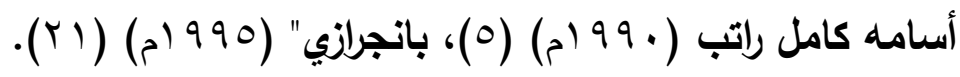
ويتضـح مـن خـلال الجدول نفسـه قيمـة (ت) المحسـوبة والتـي تتـراوح

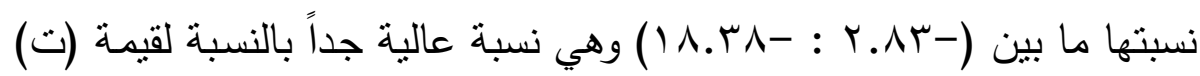
الجدولية وذلك مما يدل على مستوى دلالتها المرتفع.

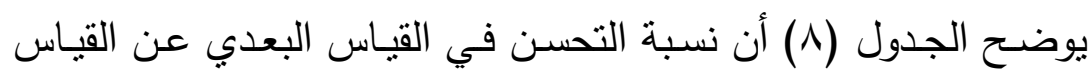

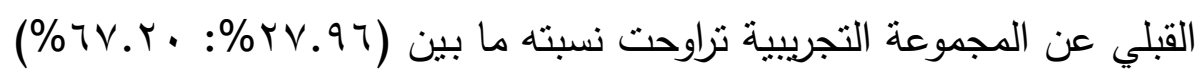
ويرجـع الباحث هذا التحسن في القياس البعدي عن القياس القبلي للبرنـامج المقترح من الباحث وما يحويه من تمرينات تساعد على تتمية المهارات الحركية الأساسية من خلال أساليب تتفيذ مشوقة ومثيرة ومناسبة لمستوى سن اللاعبين. كما يذكر كلا من "أحمد عبد الرحمن السرهيد، فريد عثمان" (س99 (م) أن النمو الحركي للطفل في هذه المرحلة يتأثز بدرجة كبيرة بالعوامل والمؤثرات

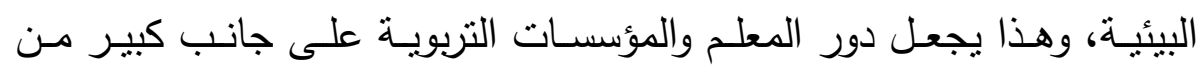
الأهمية في هذه المرحلة. (r: • V)

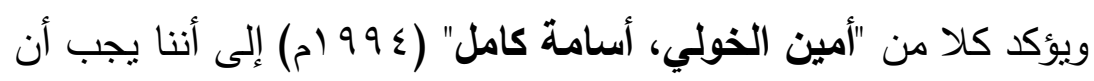
نبدأ بتعلم المهارات الحركية الأساسية فإذا ما اكتسب اللاعب الخبرة في أداء أنماطها المختلفة فإنها من السهل أن يتعلم أي مهارة حركية خاصـة بالأنشطة

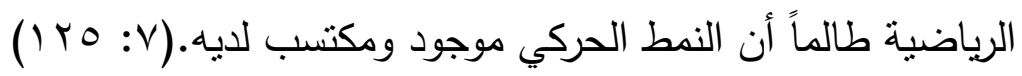

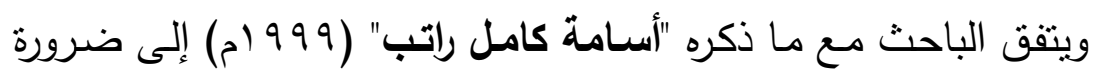
أن بصـل اللاعب إلى مسـتوى الأداء الناضـج في بعض المهارات الحركيـة الأساسية حتى ينجح في أداء المبادئ الخططية الدفاعية لكرة القدم وعلى ذلك 
فمن الصـوبة بمكان توقع اللاعب باكتساب المبادئ الخططية الدفاعيـة لكرة القدم على نحو جيد إذا ما أخفق في إجادة المهارات الحركية الأساسية المرتبطة

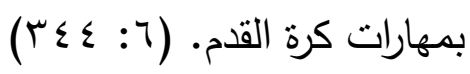

وتتفق النتائج السابقة مع دراسة كل من "محمد مرسـال حمد" (ب99 (1)

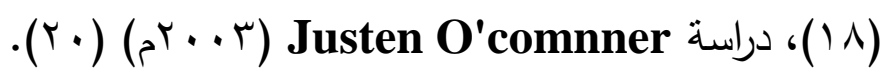

والتي توصـلت نتائجهـا إلى وجـود فـروق ذات دلالــة إحصـائية بـين متوسطي القياسين القبلي والبعدي لصالح القياس البعدي في المهارات الحركية الأساسية.

ومن خلال نتائج جدول (^) وشكل (1) فقد توصل الباحث إلى تحقيق الفرض الأول، وهو توجد فروق دالة إحصـائياً بين متوسطي القياسين القبلي

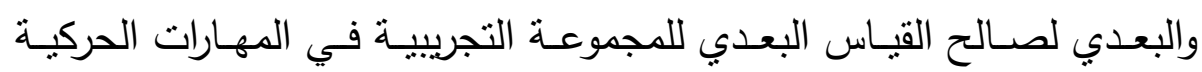
الأساسية (قبد البحث).

مناقشة نتائج الفرض الثاني الأي ينص على:

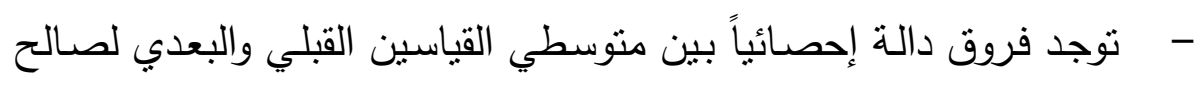
القيـاس البعـدي للمجموعـة التجريبيـة في المبـادئ الخططيـة الهجوميـة المرتبطة بكرة القدم (قيد البحث). - يتضح لنا من جدول (9) وجود فروق ذات دلالة إحصائياً بين القياسين

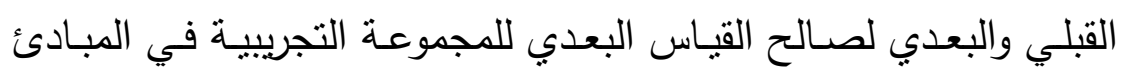

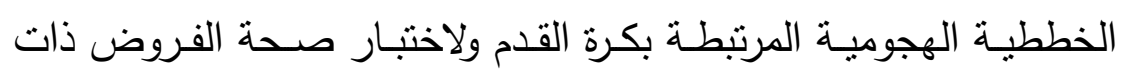
الدلالــة الإحصـائية بـين القياسـين القبلـي والبعـدي للمجموعـة التجربييـة اسـتخدام الباحـث اختبـار (ت) T test للمجموعـة التجريبيـة لمقارنـة متوسـطي درجـة اللاعبـين في القياسـين القبلـي والبعـدي في المبـادئ الخططية الهجومية لكرة القدم. 
- ويتضـح من خلال نفس الجدول وجود فروق دالة إحصـائيا عند مستوى إنـ (0 • . • بين القباسـين القبلي والبعدي في المبـادئ الخططيـة الهجوميـة

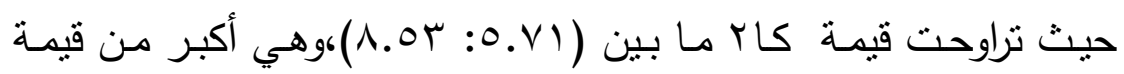
كاب الجدولية.

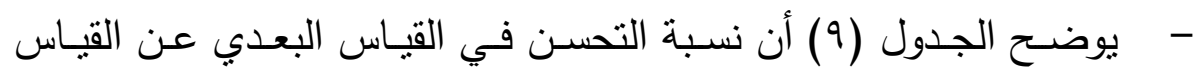

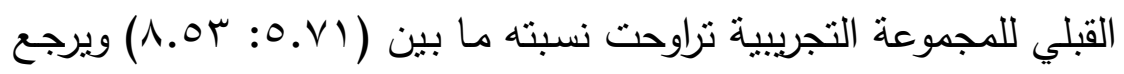
الباحث هذا التحسن في القياس البعدي عن القياس القبلي إلى البرنـامج

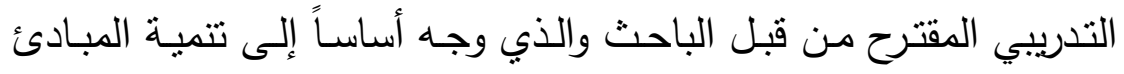
الخططية الهجومية في كرة القدم تحت إثراف وتوجيه سليم، هذا بالإضافة

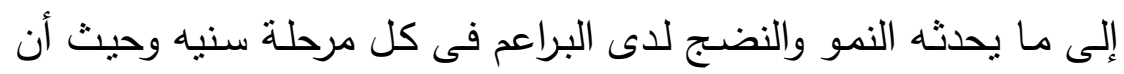

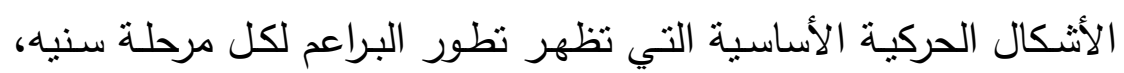

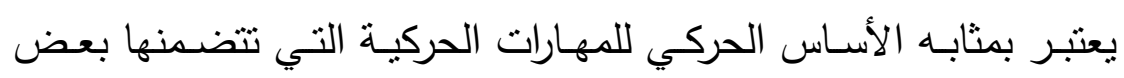
المبادئ الخططية الهجومية فى كرة القدم.

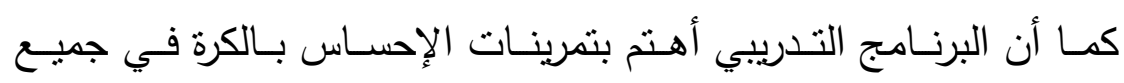

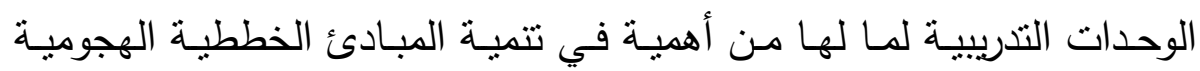
ويؤكد ذلك "محمد إبراهيم سلطان" ( . . . rم) على أهمية تدريبات الإحساس

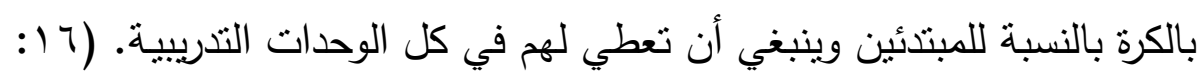

وكذلك اتبـاع الباحث الخطـوات والمراحل المتدرجـة في تعليم المبـادئ الخططية الهجومية واستخدام الأدوات المساعدة نظراً لما لها من فائدة من تعلم الدقة في الأداء وكذلك يستطيع اللاعب أن يكرر أداء المبادي الخططية بنفس

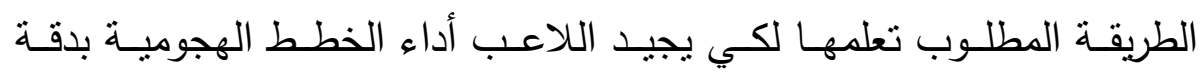
بالإضافة إلى البرنامج التدريبي المقترح من قبل الباحث. وهذا ما يؤكده معظم

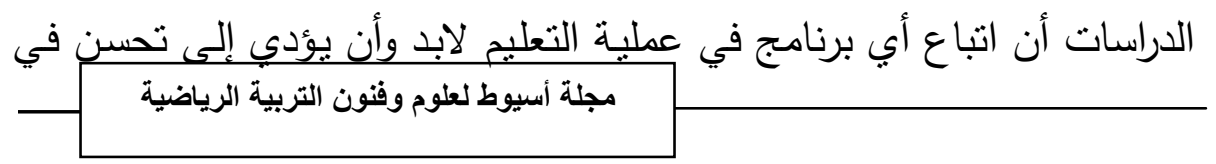


الدستوى مها كانت درجة النسبة ومن هذه الدراسات "صفية منصور ، وأميرة

$$
\text { عبد الفتاح" (919 ام) (· (1). }
$$

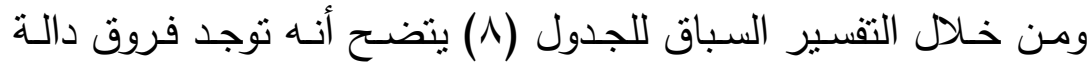

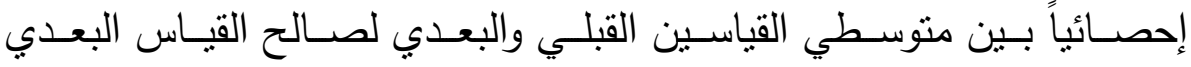

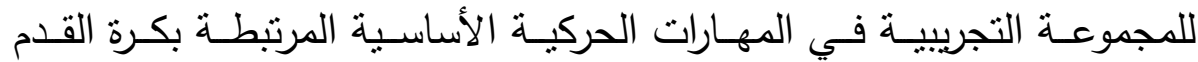

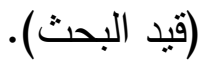

ومن خلال نتائج جدول (9) فقد توصل الباحث إلى تحقيق الفرض الثاني

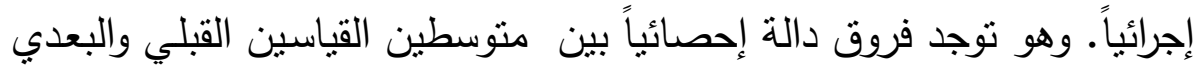

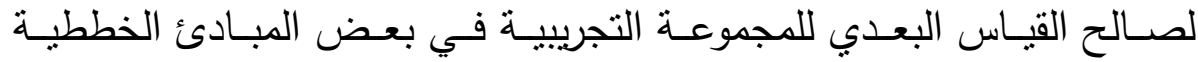
الهجومية المرتبطة بكرة القدم (قيد البحث). وجود ارتباط طردي دال إحصائيا

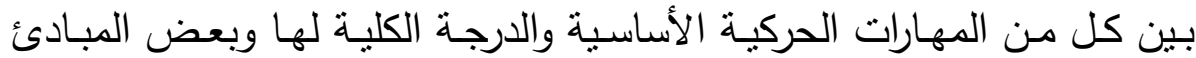

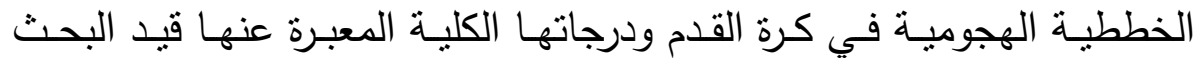
للمجموعة التجريبية حيث بلغت قيمه (ر) المحسوبة أعلى من قيمتها الجدولية

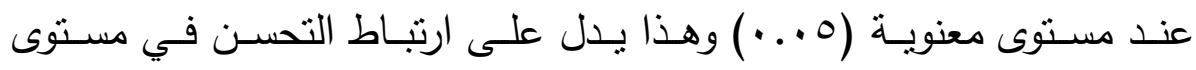

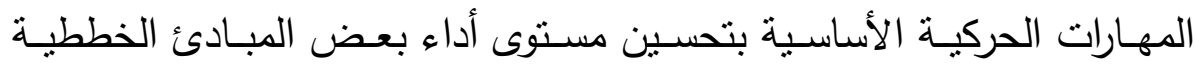

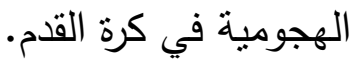

ويتفق الباحث مـع ذكرتـه "فريـدة عثمـان" (9Av ام) إلى أن المهارات

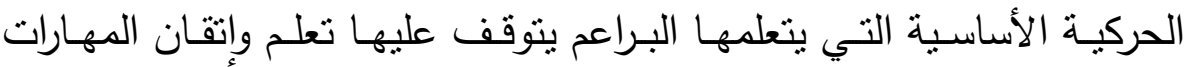

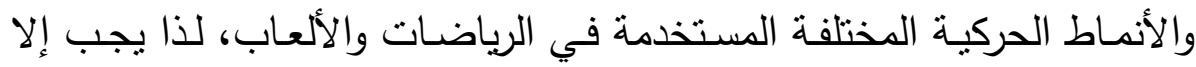
ينتقل المدرب بالبرعم من مرحلة تعلم المهارات الحركية الأساسية إلى مهارات الألعاب والرياضات إلا بعد أن يتعلم البرعم ويصل إلى درجة عالية من إتقان

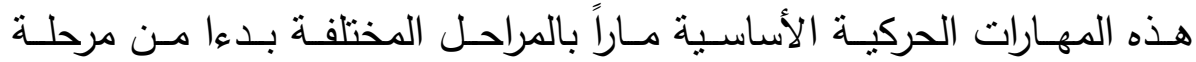

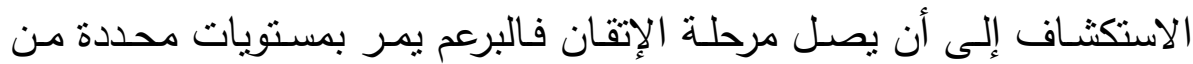

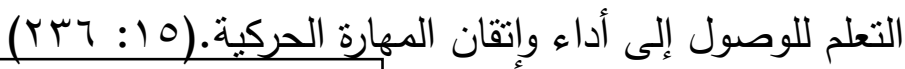
مجلة أسيوط لعلوم وفنون التربية الرياضية 
في حدود وطبيعة ومجال البحث والهذف منه وفي ضوء فروض البحث

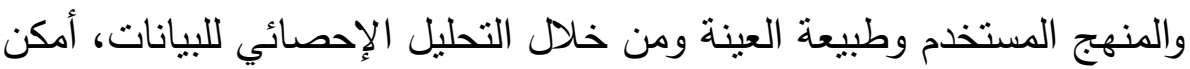
التوصل إلى الاستتاجات النالية: ا - ساهم البرنامج التدريبي المقترح بطريقة إيجابية في تتمية المهارات الحركية الأساسية المرتبطة بالمبادئ الخططية الهجومية في كرة القدم.

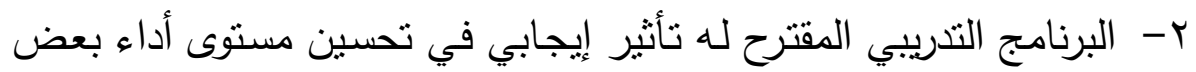
المبادئ الخططية الهجومية في كرة القدم.

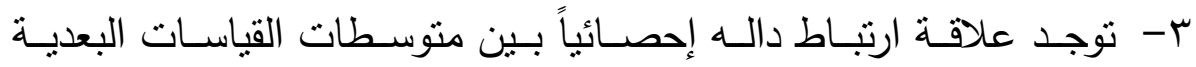
للمجموعة التجريبية في بعض المبادئ الخططية الهجومية في كرة القدم والمهارات الحركية الأساسية. ع - كلما تطورت المهارات الحركية الأساسية (قبد البحث) كلما ارتفع مستوى أداء بعض المبادئ الخططية الهجومية في كرة القدم للعينة (قبد البحث).

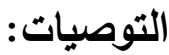

في حدود مجتمـع البحث والعينـة المختارة وفي ضوء أهداف البحث وفروضه وماتم التوصل اليه من نتائج يوصي الباحث بمايلي:

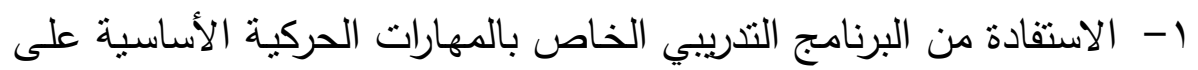
مستوي البراعم فى كرة القدم. r- الاهنمام بتتمية المهارات الحركية الأساسية قبل الثروع فى تدريب المبادئ الخططية الهجومية لبراعم كرة القدم. لبهنه

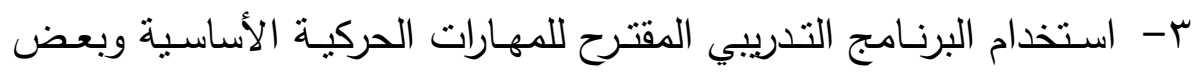
المبادئ الخططية الهجومية لدى مدربي براعم كرة القدم. ع - العمل على تجديد مواقف التدريب لإبعاد الملل من نفوس البراعم. 0- إجراء دراسات مشابهة على رباضات أخرى وعلى مراحل سنية مختلفة. مجلة أسيوط لعلوم وفنون التربية الرياضية 


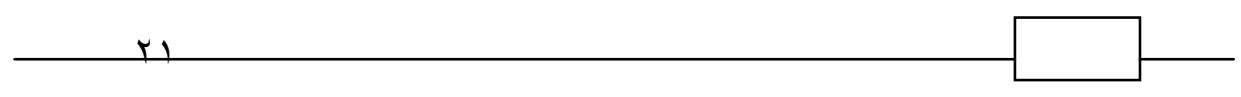

צ- البعد عن التدريب التقليدي والعمل على زيادة الدافعية للممارسة من قبل

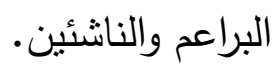




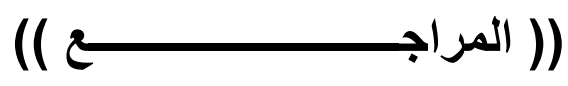 \\ أولاً: المراجع باللغة العربية}

1 - إبراهيم حنفى شعلان، عمرو أبو المجد: أسس بناء كرة القدم الثـاملة،

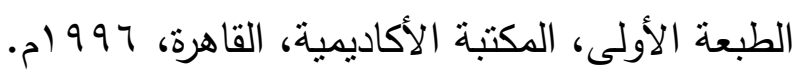

Y - إبراهيم حنفى شعلان، محمد عفيفى: كرة القدم للناشئين، مركز الكتاب

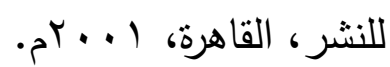

ب- أحمد عبد الـرحمن السـرهيدي، فريـدة ابـراهيم عثمـان :"الاسس العلميـة

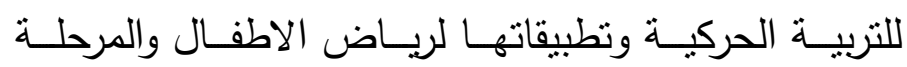

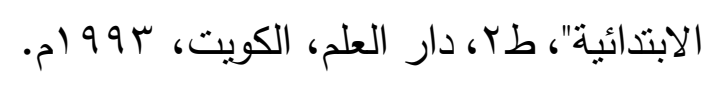

ع - أحمد محمد الهنيدى: "برنامج تدريبي للمهارات الحركية الأساسية وتأثنرها في داكي مستوى أداء بعض المهارات الأساسية لبراعم كرة القدم"، رسالة

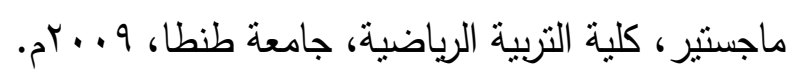

ه - أســامة كامـل راتـب: "النــو الحركي" (الطفولـة- المراهقة)، دار الفكر

$$
\text { العربي، القاهرة، • } 99 \text { (م. }
$$

צ- أســـامة كامـلـ راتــب: "النمـو الحركي"(مــــل للنمـو المتكامـل للطفـل

$$
\text { والمراهق)"، دار الفكر العربي، القاهرة، } 999 \text { (م. } 9 .
$$

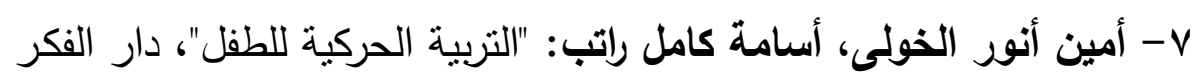

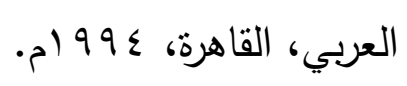

^- حنفـى محمـود مختــار : مـدرب كـرة القدم، دار الفكر العربـي، القـاهرة،

$$
\text { . } 919 \text {. }
$$

9- حنفى محمـود مختـار : "الأسس العلميـة في تدريب كرة القدم"هدار الفكر

$$
\text { العربي، القاهرة، } 999 \text { (م. }
$$

ـ 1 - صفية منصور، وأميرة عبد الفتاح: "برنامج العاب صغيرة مقترح لتطوير التهرة

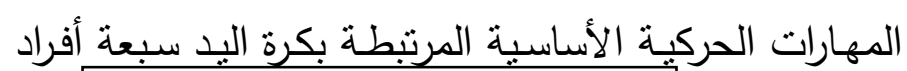


في مرحلة الطفولة المبكرة من سن 7 إلى 9 سنوات، مجلة

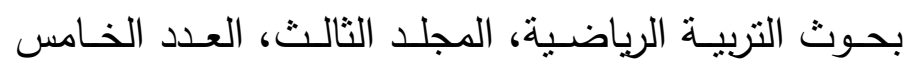

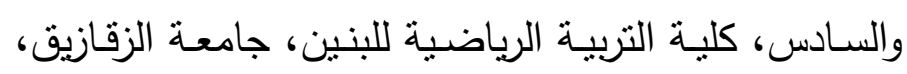

$$
\text { . } 917
$$

11 - طارق عبد المنعم على: "العلاقة بين بعض المبادئ الخططية الهجومية

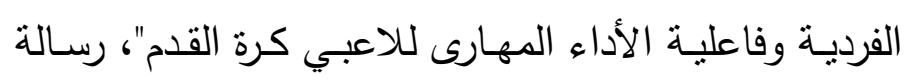

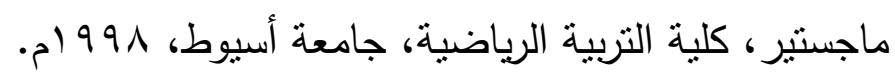

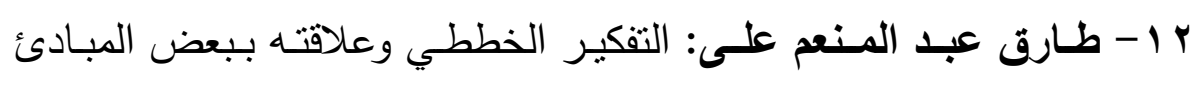

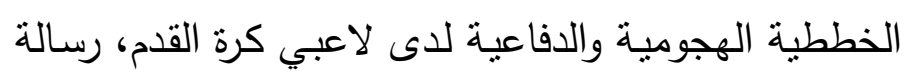

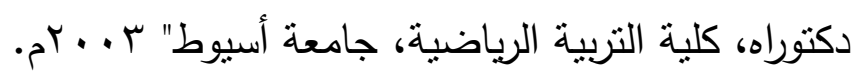

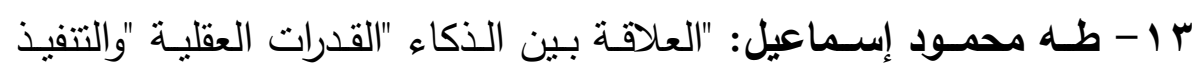

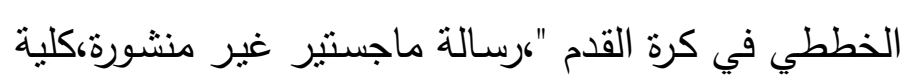

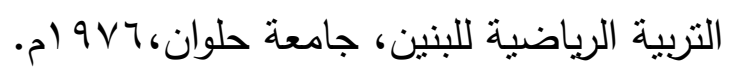

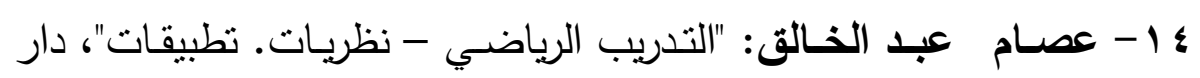

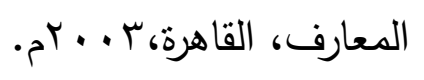

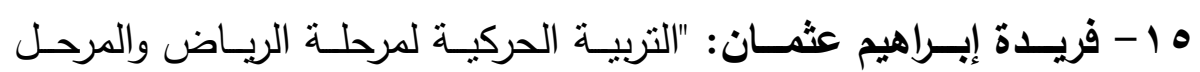

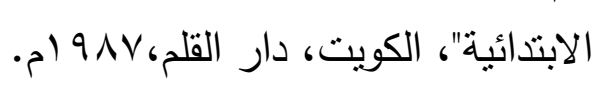

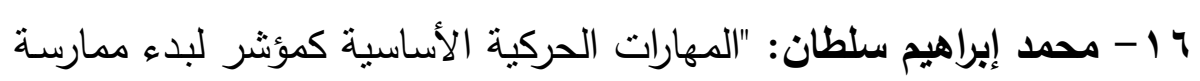

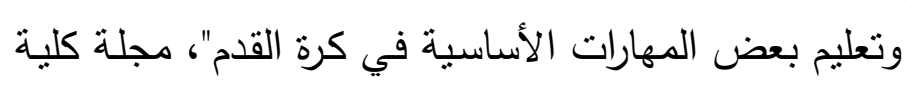

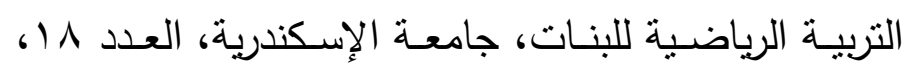

$$
\text { . }
$$

IV

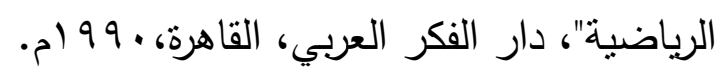

مجلة أسيوط لعلوم وفنون التربية الرياضية 


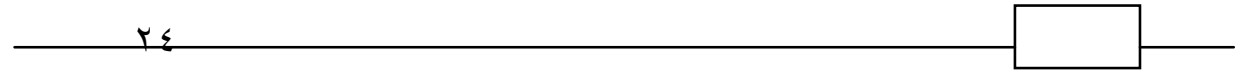

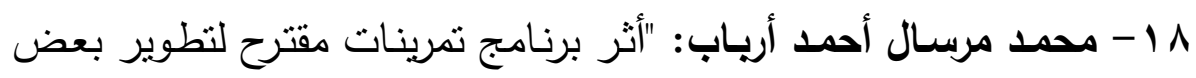

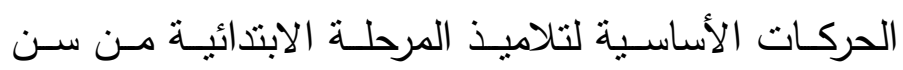

(7-9) سنوات" رسـالة دكتوراه غير منشـورة، كلية التربيـة

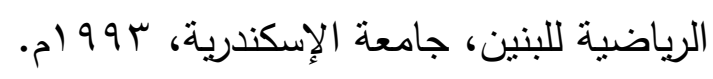

9 1 - مفتي إبراهيم حمـاد: الهجوم في كرة القدم "،دار الفكر العربي، القاهرة،

$$
\text { ثانيا المراجع باللغة الأجنبية: } 99 \text { ام. }
$$

20- Justen O'Conner (2003): Development children are our children competent? Rmit. Paperpre sented at biennial achpeh conference Jan.

21- Pangrazi, r.p \& Dauer, v.p: DyAamic physical education for elementary school children, Need ham heighes mass achusetls, 1995. 